\title{
Moral Revolutions: The Politics of Piety in the Ottoman Empire Reimagined
}

\author{
NIR SHAFIR \\ University of California, San Diego
}

The interlinking of morality, religion, and politics may not be new, but our predisposition to separate them is. A central precept of Enlightenment thought is that religion should remain in the private sphere, sequestered from the politics of the public realm. ${ }^{1}$ For this reason, fifty years since identifying "political Islam" as a theoretical issue, social scientists continue to puzzle over it. Early on, the answers to the question of religious revival in modern society were instrumentalist: people became religious to express economic frustration or exert "agency" in the face of an oppressive system. Anthropologists then turned to the question of understanding the political import of Islamic revival in its own terms. For example, Saba Mahmood famously argued in The Politics of Piety that a women's piety movement in 1990s Egypt created new political subjectivities through the cultivation of proper moral behavior. ${ }^{2}$ She contended that scholars had overlooked this development because they focused on political action within the formal world of the ballot box, replicating the Enlightenment sequestration of ethics and belief into the moral/private sphere. In other words, the question was not so much why religion had returned to public life, but how we had decided it was absent in the first place. The answer to that question

Acknowledgments: I would like to thank the late Shahab Ahmed, Elisabetta Benigni, Susanna Ferguson, Matthew Ghazarian, Matthew Keegan, Tijana Krstic, Alp Eren Topal, the anonymous $\mathrm{CSSH}$ reviewers, and many, many others for their insightful feedback on the numerous iterations of this essay. This project has
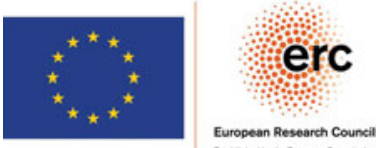
received funding from the European Research Council (ERC) under the European Union's Horizon 2020 research and innovation programme (grant agreement No 648498-OTTOCONFESSION).

1 Much literature exists on this topic, but the main points were summarized by Talal Asad in Genealogies of Religion: Discipline and Reasons of Power in Christianity and Islam (Baltimore: Johns Hopkins University Press, 1993), 204-8.

2 Saba Mahmood, Politics of Piety: The Islamic Revival and the Feminist Subject (Princeton, Princeton University Press, 2005). 
is secularism, a political project born out of the modern and colonial state. Far from being a benign desacralization, Mahmood and likeminded anthropologists argue that secularism "entails fundamental shifts in conceptions of self, time, space, ethics, and morality, as well as a reorganization of social, political, and religious life," which in turn shapes our very analyses and categories. ${ }^{3}$

The insights of anthropologists regarding contemporary Islamic revival, and secularism, can help us redefine political practice and thought in the premodern Ottoman Empire, I believe. ${ }^{4}$ Works like the poet Nābī's Hayriyye - a book of advice to his son written in 1701 and the text at the core of this essay - deserve as central a position in the formation of Ottoman political thought as that which Rousseau's Emile holds in European history. Texts like Nābī's were part of an immense body of morality literature, of which scholars have only begun to scratch the surface, that emerged as part of a widespread pietistic turn over the sixteenth and seventeenth centuries. Yet, historians have failed to see the broader political implications of this turn because, like earlier scholars of contemporary Islamic revival, we have viewed it as simply moralistic and religious and presumed that it belongs to a private rather than political world.

Furthermore, the still reigning narrative of the religious revival in the early modern Ottoman Empire, the so-called Kadizadeli movement, emerged in tandem with social scientists' initial explorations of the causes of the Islamic Revival in the 1980s. In a book coincidentally also titled The Politics of Piety, Madeline Zilfi first introduced the foundational narrative of Ottoman religious revival: in the seventeenth century, preachers professing an intolerant and orthodox Islam found popular support among unemployed provincial scholars and with this mandate made their way to power by beguiling the sultans. ${ }^{5}$ This upsurge of religiosity supposedly ended with the dismissal of the preachers following a disastrous Ottoman campaign to conquer Vienna. In Zilfi's narrative, the Kadizadelis were a paroxysmal hiccup of fundamentalism, shortlived and ultimately inconsequential. Like the social scientists who analyzed the Iranian Revolution, she provides a functionalist reading of their turn

${ }^{3}$ Saba Mahmood, Religious Difference in a Secular Age: A Minority Report (Princeton: Princeton University Press, 2016), 3.

${ }^{4}$ The foundational essays of the anthropological critique belong to Talal Asad, as in Genealogies, 200-36; and Formations of the Secular: Christianity, Islam, Modernity (Stanford: Stanford University Press, 2003). Alongside Mahmood, we can also point to Charles Hirschkind, The Ethical Soundscape: Cassette Sermons and Islamic Counterpublics (New York: Columbia University Press, 2006); and Hussein Ali Agrama, Questioning Secularism: Islam, Sovereignty, and the Rule of Law in Modern Egypt (Chicago: University of Chicago Press, 2012). For an overview of the literature on secularism, see Fenella Cannell, "The Anthropology of Secularism," Annual Review of Anthropology 39 (2010): 85-100.

5 Madeline Zilfi, The Politics of Piety: The Ottoman Ulema in the Postclassical Age (16001800) (Minneapolis: Bibliotheca Islamica, 1988); and "The Kadizadelis: Discordant Revivalism in Seventeenth-Century Istanbul," Journal of Near Eastern Studies 45, 4 (1986): 251-69. 
to religion as a means of exerting their agency in the face of economic dissatisfaction. Moreover, the Kadizadeli narrative pushes a relationship between religion and politics as separate entities, in which preachers corrupt what ought to be politics by bringing religion into the discussion. ${ }^{6}$ It is this presumption that continues today and which the anthropology of Islamic revival and secularism can help remedy. ${ }^{7}$ Along the way, such an engagement should inspire both historians and anthropologists to imagine political regimes of morality, concepts of "the social," and even formations of the secular, which emerged in the Middle East outside of the contexts of liberalism and colonial modernity.

Today we can understand a broader "turn to piety" in Ottoman society, well beyond the contours of the Kadizadeli movement, thanks to a new narrative of religious history crafted over the past ten years. ${ }^{8}$ We know now that in the early empire confessional identity was initially an afterthought, but over the sixteenth and seventeenth centuries both the state and its subjects increasingly emphasized the centrality of Islamic practice and belief, as defined by Islamic law, to imperial ideology. ${ }^{9}$ Geopolitically, imperial rivalries with the Habsburgs and the Safavids, in particular, pushed the formation of an intensely Sunni identity while, locally, congregational mosques were set up in each town and major neighborhood, becoming centers of urban life, but also social surveillance. ${ }^{10}$ Ottoman subjects redefined the boundaries of piety and Islamic practice while also becoming increasingly concerned with defining and uprooting

${ }^{6}$ Cemal Kafadar wrote the clearest exposition of the political vision of sixteenth-century pietists like Birgivī Mehmed, but even here there is a presumption of that pietists' politics is ultimately an escape or diversion from politics proper. Cemal Kafadar, "The Myth of the Golden Age: Ottoman Historical Consciousness in the Post Süleymânic Era," in Halil Inalcik and Cemal Kafadar, eds., Suleyman the Second and His Time (Istanbul: Isis Press, 1993), 37-48; Tuşalp Atiyas, E. Ekin, "The 'Sunna-Minded' Trend," in Marinos Sariyannis, A History of Ottoman Political Thought up to the Early Nineteenth Century (Leiden: Brill, 2019), 233-78.

7 Some recent works that continue to use the Kadizadeli framework are Marc Baer, Honored by the Glory of Islam: Conversion and Conquest in Ottoman Europe (New York: Oxford University Press, 2008); Simeon Evstatiev, "The Qādīzādeli Movement and the Revival of Takfir in the Ottoman Age," in Camilla Adang et al., eds., Accusations of Unbelief in Islam: A Diachronic Perspective on Takfir (Leiden: Brill, 2016), 213-43; Mustapha Sheikh, Ottoman Puritanism and Its Discontents: Ahmad al-Rumi al-Aqhisari and the Qadizadelis (Oxford: Oxford University Press, 2016); Cengiz Şişman, The Burden of Silence: Sabbatai Sevi and the Evolution of the OttomanTurkish Dönmes (New York: Oxford University Press, 2015).

8 Like Terzioğlu below, I expand the "turn to piety" from Baer's original meaning in Honored by the Glory of Islam.

9 These processes are summarized in Derin Terzioğlu, "How to Conceptualize Ottoman Sunnitization: A Historiographical Discussion," Turcica 44 (2012-2013): 301-38.

${ }^{10}$ Regarding mosques, see Gülru Necipoğlu, The Age of Sinan: Architectural Culture in the Ottoman Empire (Princeton: Princeton University Press, 2005); on inter-imperial rivalry, see Tijana Krstić, Contested Conversions to Islam: Narratives of Religious Change in the Early Modern Ottoman Empire (Stanford: Stanford University Press, 2011). 
heresy. ${ }^{11}$ This process—-which Tijana Krstić has described as "confessionalization," in a borrowing from European history - cemented a tight relationship between the public face of the empire as a Sunni polity and personal religiosity. ${ }^{12}$ This scholarship has reframed the pietistic turn in the Ottoman Empire within a longer-term and deeper religious transformation, but we have yet to examine its effects on political practice and thought. In less skilled hands, the politics of confessionalization is limited to the state's capacity to define and enforce the boundaries of religion, and for this reason I choose the broader term of "pietism" to include religious movements and changes that operate both within and without the state. And to understand the deeper shifts in political subjectivity that the pietistic transformation entailed we can look to the more recent anthropology of Islamic revival.

I argue in this essay that the pietistic turn over the sixteenth- and seventeenth-century Ottoman Empire created a new political regime of morality. It did so by insisting that all the empire's Muslim subjects, not just the sultan and elites, had the responsibility to be virtuous moral and political actors. This was an important shift in Ottoman political thought, which previously aimed only at the moral reformation of the sultan, and the result was a new political subjectivity centered on individual morality. Familial and private life became important spaces of political authority, disciplinary power, and private resistance and built the basis for the expanded, mass politics of the seventeenth century. This moral revolution touched many of the currents of Ottoman thought; pietistic reformers and jurists initiated the change, but Sufis and bureaucrats quickly followed, each envisioning a different political future stemming from a need to make ordinary subjects moral and political actors.

What follows is a demonstration of the political import of the pietistic transformation of the empire through a reinterpretation of the core political concept of nașihat. Literally meaning "advice," the long-standing concept and practice entailed exhorting fellow Muslims to lead moral lives. The stuff of politics was deciding what a moral life meant, who was supposed to lead one, and how. A ruler might exert nașīhat by ensuring that his subjects behave morally, often through the standards of the sharia, but a subject might also censure the ruler himself. Likewise, in extreme circumstances, like those I describe below, subjects or subordinates were free to reject the nașinat completely and rebel. This particular blend of moral exhortations and political sanctions makes nașihhat difficult if not impossible to translate,

11 On piety, see Katharina Anna Ivanyi, "Virtue, Piety, and the Law: A Study of Birgivī Mehmed Efendi's Al-Ṭarīqa Al-Muhammadiyya" (PhD diss., Princeton University, 2012). On heresy, see Guy Burak, "Faith, Law and Empire in the Ottoman 'Age of Confessionalization' (Fifteenth-Seventeenth Centuries): The Case of 'Renewal of Faith," Mediterranean Historical Review 28, 1 (2013): 1-23.

${ }^{12}$ Krstić, Contested Conversions. 
but it also led Talal Asad to find in nașịhat (in contemporary Saudi Arabia) both an analogue and an alternative to the Enlightenment notion of public reason and critique, a foundation of the modern liberal society. ${ }^{13}$

Nașinhat also happens to be a central concept for historians in overturning the presumption that the Ottoman Empire declined over the seventeenth and eighteenth centuries. ${ }^{14}$ The genre traditionally known as the nașinhat-näme, or "advice book," were the texts that Ottoman bureaucrats began writing in the late sixteenth century, in which they decried the corruption and malfeasance that had beset the empire. Initially, their complaints were read literally as objective statements of decline and corruption, but more recent interpretations have recast these texts as ideological representations written by state functionaries attempting to champion one political faction over another as the empire underwent radical structural shifts. The authors of these treatises, by comparing the current situation to an idealized golden age, often identified as the rule of Suleyman (r. 1520-1566), suggested reforms to remedy what they believed to be debilitating corruption and misrule.

Historians today may have misinterpreted the notion of nașinhat in their search for a refutation of the narrative of Ottoman decline. Much like scholars of contemporary Islamist movements, a general secularist bent has led us to focus too narrowly on the overtly political dimensions of nașihat, understanding it as a "mirror for princes" but not as "morally corrective criticism." 15 It is this latter meaning that has always predominated, before and after the seventeenth century. Meninski, in his dictionary of 1680, defines nașinhat as both "conseil," and "sermon," whereas Nazmīzāde's dictionary from the same

13 Asad, Genealogies, 200-36.

14 For the initial literature, see Bernard Lewis, "Some Reflections on the Decline of the Ottoman Empire," Studia Islamica 9 (1958): 111-27; Bernard Lewis, “Ottoman Observers of Ottoman Decline," Islamic Studies 1 (Mar. 1962): 71-87. For the response: Cornell Fleischer, Bureaucrat and Intellectual in the Ottoman Empire: The Historian Mustafa Ali (1541-1600) (Princeton: Princeton University Press, 1986); Pál Fodor, "State and Society, Crisis and Reform, in 15th17th Century Ottoman Mirror for Princes," Acta Orientalia Academiae Scientiarum Hungaricae 40, 2-3 (1986): 217-40; Rifaat Abou-El-Haj, "The Ottoman Nasihatname as a Discourse over 'Morality,"' in Abdeljelil Temimi, ed., Mélanges Professeur Robert Mantran (Zaghouan: Centre d'Etudes et de Recherces Ottomanes, Morisques, de Documentation et d'Information, 1988), 17-30; Cemal Kafadar, "The Question of Ottoman Decline," Harvard Middle Eastern and Islamic Review 4, 1-2 (1997-1998): 30-75; Douglas A. Howard, "Genre and Myth in the Ottoman Advice for Kings Literature," in Virginia H. Aksan and Daniel Goffman, eds., The Early Modern Ottomans: Remapping the Empire (Cambridge: Cambridge University Press, 2007), 137-66; Heather Ferguson, "Genres of Power: Constructing a Discourse of Decline in Ottoman Nasihatname," Osmanlı Araştırmalart 35 (2010): 81-116. A nice break from this is found in Derin Terzioğlu, "Sunna-Minded Sufi Preachers in Service of the Ottoman State: The Nașịhatnāme of Hasan Addressed to Murad IV," Archivum Ottomanicum 27 (2010): 241-312.

15 Asad, Genealogies, 214. Asad was aware of the Ottomanist discourse on nașinhatnames, and even read Abou-El-Haj's work (see p. 216 f. 27), but he found little of relevance. For an example of a traditional approach to political thought in the Ottoman Empire, see Linda T. Darling, A History of Social Justice and Political Power in the Middle East: The Circle of Justice from Mesopotamia to Globalization (New York: Routledge, 2013). 
period simply defines it as "a sermon and guidance toward good." enteenth and eighteenth centuries, advice books known as nasīhatnāmes or pendnāmes (pend being Persian for advice) had become exceptionally popular among the empire's inhabitants. They counseled people on how to lead morally correct lives, but often with only distant political connection. It is in these texts that we can see the true transformation of politics in the Middle East. On the other hand, the texts that historians today label "nasinhatnämes," with their specific recommendations as to the proper structure of governance, were only a small and perhaps even marginal part of the field of nașịhat.

A moment of deep political crisis at the turn of the eighteenth century provides the best vantage point from which to observe nașihat in action. In a collective act of rebellion, the different classes of Istanbul gathered and took control of the city in 1703. The imperial government in Edirne issued a final act of "advice and exhortation (nuṣ $u$ pend)," but the swelling crowd rejected the sultan's words of advice - his "nașinhatnāme" — and deposed him. ${ }^{17}$ Yet the sultan's nașinat was not the only one on offer in the marketplace of advice. In the preceding years, two men, one a şeyhülislam (the chief jurist) and the other a poet, both close to the seat of imperial power in the late seventeenth century, proffered radically different visions of nasihnat. In the wake of the 1703 rebellion, one would be declared a heretic and have his body desecrated, while the other went on to become one of the eighteenth century's most popular authors.

In the fates of these two men, Feyżullah Efendi (d. 1703) and Yūsuf Nābī (d. 1712), we can see two intertwined but distinct understandings of the relationship between religion and politics that emerged from the pietistic turn. In 1702, Feyżullah Efendi, the şeyhülislam and de facto ruler of the Ottoman Empire, set out to reform and save the empire by restoring its moral order through an imperial edict that called for the mass and compulsory education in the basics of Sunni Islam of the entire population, from nomads in the countryside to merchants in the city. Echoing a well-known hadith, he declared that "nașīhat is religion! (al-din al-nașịha),"18 and provided instructions for ensuring that proper morals were taught in all schools, from the simplest children's schools to the most prestigious madrasas. The poet Yūsuf Nābī, on the other hand, in 1701 penned the Hayriyye or Hayrināme, a book of advice addressed to his eponymous seven-year old son, Ebu'l-Hayr. It quickly became one of the

16 The Latin terms given are "monitum, consilium, documentum, exhortatio, concio," which are, not coincidently, the same terms given for "vacz," or sermon. Franciszek Meniński, Thesaurus linguarum orientalium (Viennae, 1680), 5196. Naẓmīzāde Hüseyin, Şerḥ-i Luğāt-ı Tārīh-i Vaṣṣāf, vol. 2, Süleymaniye Library, Ayasofya MS 3151, f. 321a.

${ }^{17}$ Naima Mustafa Efendi, Târih-i Na'̂̀mâ (Ravzatü'l-Hüseyn fî Hulâsati Ahbâri'l-Hâfikayn), Mehmet İpşirli, ed. (Ankara: Türk Tarih Kurumu Yayınları, 2007), 1870.

${ }_{18}$ My translation of this hadith is purposefully crude, but others, like Talal Asad, render it as "religion is integrity." Genealogies, 214-15. 
most popular books in the empire, and its position in the canon of Ottoman literature is attested by its early translation into French in the $1840 \mathrm{~s} .{ }^{19}$ In this text, Nābī counsels his son how to lead a moral life as a man, while simultaneously presenting a radical and systematic critique of Ottoman society that declares all of its institutions and classes corrupt and the government illegitimate.

Most studies of Ottoman pietistic movements have focused on the disciplinary mechanisms the state employed to enforce confessional identity, whether imposed from the top down, like Feyżullah's project, or enacted in response to the cries of those below. Nābī's formal attack against the government allows us to draw out the political import of nașinhat as moral critique, but it also reveals the ways the pietistic turn was grounded in the cultivation of the self. ${ }^{20}$ My primary focus here will be Nābī's oft-overlooked approach to nașīhat. To elucidate its importance, I first examine the role of morality in Ottoman political thought in the preceding centuries. I then sketch out the new vision of politics embedded in the pietistic turn, and compare Feyżullah and Nābī's competing projects therein. My conclusion reflects on how this premodern Ottoman case can contribute to our understanding of secularism in the Middle East.

\section{MORALITY AND GOVERNANCE IN THE SIXTEENTH CENTURY}

Nașinhat was not purely a product of the early modern pietistic turn. It existed long before as a Quranic injunction and in the words of medieval preachers and philosophers. Nor was it limited to one genre. It flourished whenever moral and political thought found themselves aligned, whether in traditional "mirror for the princes" works like the Qābūsnāma or in the genre of adab (belles-lettres), or in the especially important field of moral philosophy, akhlāq. ${ }^{21}$ What did change was the specific alignment between morality and politics embedded in nașinat, when, around the seventeenth century, politics began to revolve around the moral reformation not of the sultan but of everyday individuals.

19 The Hayriyye was actually one of the first works of Ottoman poetry translated into a Western language. Conseils de Nabi Efendi à son fils Aboul Khair, Abel Pavet de Courteille, trans. (Paris: Imprimerie impériale, 1857); Elias John Wilkinson Gibb and Edward Granville Browne, A History of Ottoman Poetry 3 (London: Luzac, 1904).

${ }^{20}$ Roger Chartier, Jacque Revel, and others first charted how the early modern privatization gave rise to new notions of the family, civility, and the self as the state exercised greater control. $A$ History of Private Life: III. Passions of the Renaissance, Arthur Goldhammer, trans. (Cambridge: Belknap Press of Harvard University Press, 1989). See also Lynn Hunt's recent call to return to explorations of the self, in Writing History in the Global Era (New York: W. W. Norton \& Company, 2014).

${ }^{21}$ For an overview of Ottoman traditions of political thought, see Marinos Sariyannis, A History of Ottoman Political Thought up to the Early Nineteenth Century. Handbook of Oriental Studies 125 (Leiden: Brill, 2019). In the South Asian context, the discursive field of nasīhat seems to have fallen primarily on the concept of "adab," instead. See Barbara Daly Metcalf, ed., Moral Conduct and Authority: The Place of Adab in South Asian Islam (Berkeley: University of California Press, 1984); Muzaffar Alam, The Languages of Political Islam: India, 1200-1800 (Chicago: University of Chicago Press, 2004), 46-80. 
In his thorough study of political thought, Hüseyin Y1lmaz has argued that between the eleventh to sixteenth centuries a new moralistic conception of rulership took hold in the Islamic world. In a post-Abbasid epoch, the mantle of rulership could potentially fall upon any ruler rather than on a caliph who fulfilled very specific requirements. In response to these open-ended possibilities, the predominantly Sufi writers that Yilmaz studies aimed to "endow the ruler with noble traits by changing his character for the better."22 Therefore, in the sixteenth century, "one of the central questions of political theory during the age of Sūleymān" was how "to reform the ruler for moral and spiritual worthiness of God-given rulership." ${ }^{23}$ In other words, political theory centered not on the construction of ideal institutions but on molding the ruler into an ideal person. These discussions, in turn, created a set of values and expectations of a ruler's moral constitution that underlay all conceptions of legitimate rule by circulating among a broader reading public.

Ensuring the moral perfection of the sultan was important because his role was to mediate conflict between his subjects. As Cemal Kafadar explains, "in Ottoman political thought, sultanic authority has to be the absolute arbiter of all social conflict. The pursuit of self- or group-interest is only to be expected of the subjects, but the ideal ruler is one who would steer the course of [the] state in adherence to certain absolute principles above and beyond the muddy waters of worldly interest...."24 In the nasīhatnāme literature upon which historians have traditionally focused, authors divided society into different estates or status groups (military, scribal, clerical, etc.) and advised the sultan on how to remedy the transgressions and usurpation of estate by individuals. The calls for reform may have differed from one work to another, but the sultan's morality remained the overall locus for these authors in their attempts to change society.

It is important to note, though, that in this earlier period the capacity for human disposition to be trained and molded was not universal but rather restricted to an elite. ${ }^{25}$ For the rest, there was the law (sharia), which operated as a system to ensure moral behavior from those who were incapable of changing their nature. This hierarchal system underlay all the moral philosophies. As Nāṣir al-Dīn al-Ṭūsī, the founder of the genre, stated in his Ethics, "Thus, some men are good by nature, while others are good by religious legislation. The instruction of this latter class in the Religious Law is like administering water to a person who has a morsel stuck in his throat: if they be not disciplined

22 Hüseyin Y1lmaz, Caliphate Redefined: The Mystical Turn in Ottoman Political Thought (Princeton: Princeton University Press, 2018), 167.

23 Ibid., 169.

24 Kafadar, "Myth of the Golden Age," 46.

25 For examples like differentiating between commoners ('awāmm) and elites (khawāsș), see Shahab Ahmed, What Is Islam? The Importance of Being Islamic (Princeton: Princeton University Press, 2016), 368-77. 
in accordance with the Religious Law, then like that person they will surely perish, for no stratagem is effective in reforming them." ${ }^{, 26}$ The superior position of the morally trained in regard to the law-abiding explains why this elite often partook in acts, like wine drinking, that were strictly forbidden by the religious law (sharia). ${ }^{27}$ It also explains why Ottoman princes until the seventeenth century received little training in the jurisprudence of Islamic law. ${ }^{28}$

The line between elites and non-elites was difficult if not impossible to cross. Justice was conceived as stability within the hierarchy, with each segment of the population remaining within its position. ${ }^{29}$ The moral education of the lower classes, who were incapable of changing their natures, was regarded as waste of time and even dangerous. The Gulistān of Sa ${ }^{c} \overline{1}$, a medieval Persian collection of parables read by nearly everyone with even the most basic education, is replete with tales of such failures. A vizier educates a bandit boy as his own son, teaching him all the arts and graces of elite society, only to have the boy murder him and his sons, steal his wealth, and run off to join the bandits again. The king quips, "How can anyone make a good sword out of bad iron? A nobody will not become a somebody through education."

In this rough sketch we can see that during the fifteenth and sixteenth centuries morality literature was always present, but it focused on the figure of the sultan as the vessel through which proper morality was to be enacted in the society. This morality, however, was not necessarily equated with the sharia, which was regarded primarily as a path for those beyond education. This point is doubly important because, as Shahab Ahmed and others have observed, law - that is the sharia - only became the primary means of being Muslim in the modern period. Thus, the impact of the pietistic turn was two-fold. It decisively changed the object of moral reform by insisting that all Muslims could become objects of moral edification and reform, and it centered this moral education on the sharia. Over the course of the seventeenth century a new conception of nașinhat, one focused on the moral responsibility of individuals, would create political actors out of ordinary subjects in the empire.

\section{THE POLITICAL IMPLICATIONS OF THE PIETISTIC TURN}

The pietistic transformation of the empire over the sixteenth and seventeenth centuries led to a greater scrutiny of ordinary subjects' morality in all aspects

\footnotetext{
26 Nasir al-Din Muhammad ibn Muhammad al-Tusi and G. M. Wickens, The Nasirean Ethics (London: Allen \& Unwin, 1964), 210.

${ }^{27}$ I thank the late Shahab Ahmed for alerting me to Tusi's insights. Ahmed, What Is Islam?, 5771; Y1lmaz, Caliphate Redefined, 175.

28 Yilmaz, Caliphate Redefined, 3.

29 Nasir al-Din Muhammad ibn Muhammad al-Tusi and G. M. Wickens, The Nasirean Ethics (London: Allen \& Unwin, 1964), 217.

30 Sa'di and Wheeler M. Thackston, The Gulistan (Rose Garden) of Sa'di (Bethesda: Ibex Publishers, 2008), 17.
} 
of life, which made the ruler the champion of this new moral order but also subject to its rules. As noted earlier, much of the new scrutiny came from the disciplinary state as it started to enforce confessional boundaries and change the religious environment. Seventeenth-century writers often talked about the need to be wary of the "hidden, internal enemies" of Islam, who superficially resembled law-abiding Muslims but secretly harbored heretical beliefs. ${ }^{31}$ One could root out the heretic from the faithful only by dissecting their actions, which, more clearly than their words, revealed their true intentions. This novel understanding of heresy is precisely what şeyhülislam Minkārīzāde (d. 1678) tried to formalize legally when he argued that heresy could be established not only, as traditionally, through the act of publicly denying the Prophet Muhammad and God, but also through a person's quotidian actions. ${ }^{32}$

The increased scrutiny of public morality was performed under a new spotlight and on a new stage: the burgeoning urban centers of the Ottoman Empire. Streets, coffeehouses, mosques, and bathhouses provided expanded spaces in which to display the newfound wealth of those members of Ottoman society who had wormed their way into the state. New goods like coffee and tobacco provided a ready visual vocabulary of heresy and unbelief and small luxuries like cheap furs and silks a space for individualization. ${ }^{33}$ These spaces of display were also spaces for public debates of these same topics, incited by preachers, who were often called the "people of nașinhat." One typical but anonymous moralist and author, detailed in a formative article of Derin Terzioğlu, went by the simple, telling sobriquet of Nușhi, Advice-Giver or Preacher. ${ }^{34}$

A preacher's spoken exhortations were one obvious vector of nașīhat, but written works moved just as quickly through the streets, mosques, and coffeehouses. Given the need to define and debate which practices were heretical, it is no surprise that morality handbooks flourished as a genre, read privately or aloud. They quickly informed readers and listeners as to proper Islamic behavior. These myriad texts, copied as full books or onto the margins or extra leaves of manuscripts, had various generic titles: hundreds are simply known as nașihhat or pend, while others were referred to as vașiyet (advice, commands),

\footnotetext{
31 See, for example, the early seventeenth-century heresiography of Mehmed Emīn b. Sadreddīn eş-Şirvānī, Süleymaniye Library, Darülmesnevi MS 258, ff. 83ab. More detailed examples are in Derin Terzioğlu, "Where Ilm-i Hal Meets Catechism: Islamic Manuals of Religious Instruction in the Ottoman Empire in the Age of Confessionalization," Past \& Present 220 (2013): 79-114, 91.

32 Letter to Khayraddīn al-Ramlī, Süleymaniye Library, Reşid Efendi MS 1215 ff. 187a-92b.

33 For debates on coffee and tobacco, see Ralph Hattox, Coffee and Coffeehouses: The Origins of a Social Beverage in the Medieval Near East (Seattle: University of Washington Press, 1985); James Grehan, "Smoking and 'Early Modern' Sociability: The Great Tobacco Debate in the Ottoman Middle East (Seventeenth to Eighteenth Centuries)," American Historical Review 111, 5 (2006): 1352-77. Regarding consumption and the stimulation of the individual self, see Hunt, Writing History, 134-43.

34 Terzioğlu, "Ilm-i Hal."
} 
or ' $a k \bar{a}$ 'id (creed), or some other combination thereof. Together, they comprised a mass of morality literature that ranged from brief, simple poems in Turkish denigrating tobacco smoking, to complex and heady academic discussions on the nature of nașinhat.

When the morality manuals that initiated the pietistic shift in the sixteenth century first appeared, they focused largely on ensuring that Muslims followed basic ritual actions such as daily ablutions and prayers, and in doing so prioritized law as the primary approach to Islam. ${ }^{35}$ Yet, by the seventeenth century, their scope expanded to focus on all aspects of life. Hamza Efendi, the author of highly popular catechistic text explained that he wrote it because pietists like the famous Birgivī Mehmed (d. 1573) had written plenty on proper belief and prayers, but had neglected all the other aspects of daily life, such as how to buy and sell goods ethically. ${ }^{36}$ Another writer, Ebu'l-Bekā el-Kefevī (d. 1684), better known today for his dictionary of philosophical and academic terminology than for his moralistic works, rendered compilations of legal rulings into easily actionable statements on topics like inheritance, childbirth, or medical procedures. ${ }^{37}$

These morality manuals implicitly, and at times explicitly, propagated an image of imperial governance as a hierarchical family. Obedience was owed first to God and the prophets, then to the sultan, and after that to the preachers and shaykhs who exhorted the masses and instructed fathers, who then disciplined their wives and consorts, who in turn raised the children. ${ }^{38}$ The aforementioned Nușhī, or "Advisor," regarded the household as the key space of instruction and societal order, in which wives and children, slaves and servants, were to be instructed in the proper path. ${ }^{39}$ This particularly gendered vision of imperial and domestic order went further than a simple familial metaphor and often entailed telling listeners how they should structure their very families. ${ }^{40}$ Kefevī, mentioned earlier, proposed a vision of an ideal nuclear family by telling men to limit themselves to only one wife and not take any others or even a concubine. Women, in turn, needed to be kept out of crowds or any places where they might see attractive youths. ${ }^{41}$ Much of this nașịhat extended itself beyond regulating public behavior and into private thoughts and

35 See Tijana Krstic, “State and Religion, 'Sunnitization' and 'Confessionalism' in Süleyman's time," in P. Fodor, ed., The Battle for Central Europe: The Siege of Szigetvar and the Death of Suleyman the Magnificent and Nicholas Zrinyi (Leiden, Boston, Budapest: Brill and Hungarian Academy of Sciences, 2019), 65-92.

${ }^{36}$ Hamza Efendi, Risāle-i Bey $u$ Şirā, Dar al-Kutub, Majāmī‘ Turkī Tal'áat MS 131, f. $91 b$.

37 Ebu'l-Bekāā el-Kefevī, Tuḥfe-i Şāhān, Süleymaniye Library, Kasidecizade MS 249.

38 Kefevī, Tuhfe-i Şāhān, ff. 140b-43a.

39 Terzioğlu, "Ilm-i Hal," 98.

40 A popular yet unstudied morality manual of the sixteenth century is Adābü'l-Menāzil by 'Abdullațif b. Durmus b. Selīm, which focuses on rulings for household members like women, children, and slaves.

${ }^{41}$ Kefevī, Tuhfe-i Şāhān, f. $141 \mathrm{~b}$. 
conversations. In Kefevī's vision of nașīhat, women had to be stopped from consulting "skeptical old hags who knew nothing about religion and piety," on important matters, or even gossiping with other women about their secrets. $^{42}$ Like other providers of nașinhat, he even advised what types of books were acceptable and unacceptable; ${ }^{43}$ women in particular needed to be "kept away from reading or listening to romances and comedies." 44 Maintaining order within the family became the key to maintaining order within the empire, since only a proper family could raise proper (Muslim) political subjects.

In this hierarchical vision of empire as family, the sultan was owed obedience but was also largely expected to be a pious exemplar himself, both championing the religious law_-sharia_-and following its prescriptions. Many of the morality and advice manuals, even when they focused on imparting morality to all of society's members, had a section of advice aimed at the sultan. Consider the work of şeyhülislam Debbāğzāde Mehmed Efendi (r. 1687-1690). In his rather academic treatise on nașīhat, which aimed to buttress the concept with classical examples derived from hadith, he advised the sultan that he must avoid companions of poor morals, since "it is impossible to reform your subjects while you are with the corrupted." Doing so would be like "trying to get the body to stand without a sound head." 45 The political failures of the empire could be corrected only if everyone maintained a proper morality. Minḳārī 'Alī Halīfe, a palace employee who seems to have specialized in explaining religious matters to children and women, presented his masterwork, The Remedy of the Faithful, to the eleven-year-old Sultan Mehmed IV. ${ }^{46}$ This work of nașinhat - which proved quite popular and came with the endorsement of the şeyhülislam, the former chief judge of Istanbul, and the sultan's imamwas a giant array of quotations from Arabic and Persian jurisprudential sources, translated into Turkish, and arranged according to matters such as prayer, marriage, and more. The introduction makes the clear case to the boy sultan that he needs to depart from past princes' ignorance and become knowledgeable in sharia. ${ }^{47}$ This was no longer something that concerned only the masses, because his legitimacy as a sultan rested on his personal knowledge and application of the sharia. ${ }^{48}$

42 Ibid.

43 Terzioğlu, "Ilm-i Hal," 96.

${ }^{44}$ Kefevī, Tuhfe-i Şăhān, f. 141b.

45 Debbāğzāde Mehmed Efendi, Rashhat al-Nașịh min al-Hadīth al-Sahịhh, Süleymaniye Library, MS Ayasofya 1822, ff. $92 \mathrm{~b}$.

46 Şifä̈̈’l-Mü'mininn, İstanbul Belediyesi Atatürk Kitaplı̆̆ı, MS OE 5.

47 See note 28.

48 Referring to an older work of political theory, the author put forward the question directly, "To what degree does the emperor of Islam need the sciences of the sharia?" Şifäü'1-Mü'minīn, ff. 9ab. 
The flood of nasinhat in the above examples may appear to be the sole prerogative of reformers who argued for the primacy of the sharia, and indeed they were most likely the swiftest stream, but nașinhat as correct moral action came together from many different branches of Ottoman culture. Literati at the upper echelons of society who wanted pearls of advice demonstrated through classical Arabic literature could turn to The Book of Distinction by Ibn Man, the former Ottoman ambassador to the Mughal Empire (and the son of the notorious Druze rebel). ${ }^{49}$ Others could also look to Hıfzị Mehmed's huge compilation The Virtues of Pious Deeds. Completed around 1677 after a grueling seven years of work, it details over two long volumes, in the simplest Turkish, how to lead a life of moral action. Drawing upon examples from the lives of the prophets and quoting heavily from Muhammad's pious companions like Abu Hurayra, he not only guided readers through the basics of prayer but also addressed questions of sexual preference (he came out against sleeping with men) and family life. While this might strike us as a supposedly sharia-minded work, based solely on jurists' law, another picture emerges from his two surviving notebooks, which detail the many texts he read as he prepared his magnum opus. ${ }^{50} \mathrm{He}$ immersed himself in the work of medieval Sufi poets like Ibn Fārid, but also in treatises of notable seventeenth-century Sufi scholars such as Sivāsī, Hüdaī, and a variety of slightly less famous ones. Many of these treatises explained not only how to be a disciple but also offered advice, that is nașịhat, to kings and Sufis alike. When we look at the works explicitly labeled as "nașinhat" in his notebook, he drew on a generic advice book in Turkish (labeled simply "pendnāme"), but also on the "nasīhat" of Aristotle, Plato, and the ancient Persian king Anushirvan. These varied sources of nașinhat attest to the concept's pull among many segments of Ottoman society and how authors drew upon different traditions of moral betterment.

The overwhelming numbers of nașīhatnāmes, morality guides, and catechisms that proliferated in the seventeenth century were united by their emphasis on the cultivation of an individual morality, but they also competed for readers' attentions. One of the most popular was the Persian text known as the Pendnāme (tr.) / Pandnāma (pr.) (Book of Advice), falsely attributed to the famous thirteenth-century Persian poet Attar. First becoming popular in the Ottoman Empire in the mid- to late sixteenth-century, it instructed its readers, as did all the morality manuals, in how to eat, pray, and love (to use our contemporary parlance). It is important because it inspired myriad transla-

\footnotetext{
49 Husayn b. Fakhraddīn b. Korkmaz al-Ma'nī, Kitāb al-Tamȳ̄z, Muhammad `Adnān Bakhīt and Nūfān al-Hammūd al-Sawārīh, eds. (Amman: Dar al-Shuruq, 2001), 39.

${ }^{50}$ His wife, Fāṭma endowed his notebooks to preserve his legacy. Süleymaniye Library, Hacı Mahmud Efendi MS 3768 f. iia, 79a; Fatih MS 5385 states on f. 309a that he spent three years preparing it and completed it in $1079 \mathrm{~h}$.
} 
tions, commentaries, and additions over the next three centuries. ${ }^{51}$ In the boisterous market of nașinhat, however, the Pandnäma and its many imitators were seen as competitors by preachers, who pursued a nasịhat centered on law. The aforementioned Nușhī singled out the entire genre of pendnāmes as a particularly distracting menace. ${ }^{52}$ This might be because these texts developed a model of moral and ethical behavior that drew from sources other than the religious law and targeted an audience with more Sufistic sympathies. Likewise, they never explicitly called upon the state to enforce a moral code upon the people through its disciplinary power. Throughout the seventeenth century there was a constant tension between the desire to cultivate morality in the self and have the state impose it from above.

Regardless of their approach, these advice manuals marked a departure from the relationship between morality and rulership of earlier centuries. They no longer focused on ensuring the sultan's moral perfection and instead established a moral axis that extended from the private homes of ordinary people to the sultan's palace, bypassing the gossiping salons of drunken poets and bureaucrats. Moreover, in this vision, all were equally responsible to behave ethically and be individually responsible for their moral burdens. It dismantled the distinction between moral philosophy for the elite and the law for the uneducated masses; sultans were now subject to the sharia, too, while townspeople needed to scrutinize their behavior. The self-reflection inherent in these pietistic and moralistic texts advanced an egalitarian individualization of moral and political subjectivity. In this ground Feyżullah and Nābī planted their visions for the political reform of the empire.

FEYZULLAH'S NASTI İHT

At the height of his power, Feyżullah Efendi turned the office of şeyhülislam (chief jurist) into a vehicle for ruling the empire in all but name. One of his most ambitious orders, a decree that set out to rebuild the empire, was the mass application of nașihat in 1702. He ordered that every Muslim subject of the empire, from the highest noble to the lowliest nomad, in every province, town, and village, be drilled in the basics of Islamic practice and thought. The endeavor was not to last, however, for a bit over a year later a revolt erupted that resulted in the deposition of Sultan Mustafa II and the brutal death of Feyżullah. After being tortured for days, Feyżullah was paraded through the square

\footnotetext{
51 A number of texts were labeled as the Pendname by the late sixteenth century, but shortly thereafter a particular version of pseudo-Attar became canonical. The text is pseudonymous because it seems that it was a sixteenth-century attribution to the medieval poet Attar (d. 1220). There are hundreds if not thousands of copies of the Pendname extant in the former Ottoman Empire, not to mention the twenty to thirty commentaries and translations on it. For a partial list, see Helmut Ritter, "Fariduddin Attar IV," Oriens 13/14 (1960-1961): 228-39.

52 See Mebāhịs-i Imān, Süleymaniye Library, Yazma Bağışlar MS 5563, f. 71b. Reference via Terzioğlu, "Ilm-i Hal," 96.
} 
backward on a draft horse as the crowd heckled him, until he was finally called a heretic and unceremoniously beheaded. The soldiers then tied ropes to the feet of his headless corpse and forced Greek priests in full ceremonial garb to drag it around the city as they wafted incense and muttered the Christian rites over the body, before finally tossing it into the river. ${ }^{53}$

How did Feyżullah climb to the peak of piety as leader of the believers, only to fall as a debased heretic? He first entered the stage of Istanbul in 1661 as a twenty-four-year-old provincial scholar summoned by his mentor, teacher, and future father-in-law, Vān̄i Meḥmed Efendi. Vān̄i Efendi, now often referred to as the last of the so-called Kadizadeli preachers, met the young scholar when he was teaching in Erzurum and brought him along when the elder became the sultan's personal preacher. Feyżullah's family, who were well-regarded Sufi shaykhs and scholars renowned for their miracles and scholarship, had only migrated to Erzurum a few decades before from Karabagh, whence they had fled the vicious sectarian persecution of the Safavids in the early 1600s. ${ }^{54}$ Once established in Istanbul as a muderris (professor), Feyzullah quickly gained entrance to the palace as the tutor of the young princes, the future sultans Mustafa II and Ahmed III. He became şeyhülislam for a brief sixteen days in 1688 in the wake of the revolts that unseated Mehmed IV, but was quickly dismissed and expelled to his hometown of Erzurum. Only when his former pupil, Mustafa II, was enthroned was he brought back to the capital and reinstated as şeyhülislam. ${ }^{55}$

Upon becoming şeyhülislam for a second time in 1695, he quickly moved to consolidate his power, placing his sons in key positions, isolating the grand vizier, and making himself the true center of the government by 1700 . The chroniclers, embedded within the palace circles, stress the extraordinary heights of Feyżullah's nepotism and his monopolization of all the posts and benefits of government for his own household, a position that continues to be reflected in understandings of the revolt as the "Edirne Incident" in scholarship today. ${ }^{56}$ While that portrayal might certainly be true, the revolt of 1703

\footnotetext{
53 Anonymous History, Berlin Staatsbibliothek, MS Diez A quart. 5, ff. 42b-43a, MS Diez A quart. 75, f. 268b; Balatlı Georg, "Balatlı Georg'a göre Edirne Vakası," Hrand Andreasyan, trans., Istanbul Üniversitesi Edebiyat Fakültesi Tarih Dergisi 11, 15 (1960): 47-64. 62; Sabra Follett Meservey, "Feyzullah Efendi: An Ottoman Şeyhülislam" (PhD diss., Princeton University, 1966), 142.

54 Feyżullah Efendi, in his autobiography, researches his own genealogy in the Ottoman archives: Harvard University, Houghton Library MS Arab 113. Regarding his ancestors, see specifically ff. 2b-5a. For a Turkish description and partial translation, see Fahri C. Derin, "Şeyhülislâm Feyzullah Efendi'nin Nesebi Hakkında Bir Risâle,” İstanbul Üniversitesi Edebiyat Fakültesi Tarih Dergisi 14 (Eylül 1959): 97-104; Ahmed Türek and F. Çetin Derin, "Feyzullah Efendi'nin Kendi Kalemden Hal Tercümesi (Pts. 1 and 2)," Ístanbul Üniversitesi Edebiyat Fakültesi Tarih Dergisi 23 (Mar. 1969): 204-18, and 24 (Mar. 1970): 69-92.

55 A detailed biography is in Meservey, "Feyzullah Efendi."

56 Rifa'at Abou-El-Haj, The 1703 Rebellion and the Structure of Ottoman Politics (Leiden: Nederlands Historisch-Archaeologisch Instituut te İstanbul, 1984); A detailed analysis of Feyżullah
} 
was unique in that it united the entire population of the empire against Feyżullah. The spark of the armorers' corps' protest set fire to the city of Istanbul as soldiers and artisans, scholars and students, merchants and riff-raff joined together to take over the city and bring down the government. How did he manage to alienate such a large swathe of the population? Why did Janissaries poets, Armenian chroniclers, and foreign diplomats all refer to him as a "heretic mufti (klzılbāş müfti)?" From these sources a more contentious image emerges: heretic and infidel (kızılbāş, kāfir), the "son of a Shi'a (Acem ferzendi)" who "transformed our faith and religion." ${ }^{57}$ Claims such as these suggest that the case against Feyżullah involved more than mere palace intrigues and addressed his grander ambitions to transform Ottoman society.

The mass application of nasihhat was one of these ambitions. Feyżullah had many others, such as a possible restructuring of Ottoman legal reasoning, but let us focus on his usage of nasīhat ${ }^{58}$ The plan seems to have been executed in stages, applied in one area and then the next. The first order, sent around the beginning of March of 1702, seems to have been directed at the Muslims of Bosnia, who were perceived to be particularly impious. A month later, the same exact orders were sent out to the ten or so provinces of greater Albania. In these initial orders, the problem was quite explicit: people in the towns and villages were destroying (helāk) the empire by "abandoning and ignoring" the sharia and sunna and this necessitated a campaign of reeducation through specially assigned teams of missionaries to "forbid the wrong and enjoin the good." These religious shock troops were supposed to teach the basic catechism ( $i l m-i h \bar{a} l$ ) such as prayers, fasts, pilgrimages, and more to the entire population in "villages and towns, near and far," focusing especially on the "semi-literate and commoners (ümmi ve 'ämme)." "59 Yet we know that Feyżullah also believed that even the highest elites should receive such training. Upon becoming şeyhülislam in February of 1696, he officially endorsed

Efendi's family politics is in Michael Nizri, Ottoman High Politics and the Ulema Household (New York: Palgrave Macmillan, 2014).

57 For the Janisarry poem(s) on the revolt, see two partial renditions by Riża Mehmed in the Vatican Library, MS Borg.turc.39, ff. 96a-99b. A particular translation is appended to Fariba Zarinebaf, Crime and Punishment in Istanbul: 1700-1800 (Berkeley: University of California Press, 2010), 183-86. See also Mehmet Halit Bayri, "Aşık Mehmet Rıza," Ülkü, III. Ser. 4 (1947): 89, 8; "Balatlı Georg,," 48-49, 52; Meservey, "Feyzullah Efendi," 146.

58 This was an attempt to replace completely legal references to the $k \bar{a} n \bar{u} n$ with those from the sharia. The significance of this decision has yet to be fully investigated although the topic has been debated for nearly a hundred years: for example, Baki Tezcan, The Second Ottoman Empire: Political and Social Transformation in the Early Modern World (New York: Cambridge University Press, 2010), 27-28; Uriel Heyd, Studies in Old Ottoman Criminal Law, V. L Ménage, ed. (Oxford: Clarendon Press, 1973), 154-55. For the original, see Başbakanlık Osmanlı Arşivi (henceforth BOA) A.DVNSNMH.d108: order 1251 (p. 293).

59 BOA A.DVNSMHM.d112: 551, 665 (pp. 156, 185). On the significance and translation of ümmi, see Terzioğlu, "Ilm-i Hal," 90-91. 
the aforementioned Minḳārī 'Ali Halīfe's book of nașīhat that insisted the sultan himself should be fully literate in fiqh and sharia. ${ }^{60}$

A month later, the experiment was expanded to cover the rest of the empire and a month after that an order specifically targeting Istanbul was dispatched. ${ }^{61}$ City folk and nomads (eșhāb-i ahbiye), elders and schoolchildren were to be taught and made to maintain the pillars of Islamic practice such as prayer, fasting, and pilgrimage. A madrasa graduate was assigned to live among rural and nomadic communities to insist that they build schools and mosques and then ensure that they were attended. This idea followed naturally from the order's particular attention to children's schools and their curricula. The rather elaborate plan obviously required a capable and willing cadre of instructors, so the initial parts of the order called for the testing and, if necessary, replacement of all preachers, professors, schoolteachers, and minders who possessed limited or partial knowledge in these fields. They were told to exhort the population to follow the right path without inciting hatred (bağża $)$, rancor (şahnnā), or fanaticism (táașub) by employing only respectable sources-fiqh, hadìth, and the like - rather than embellish tales and spurious facts. A plan of such ambition no doubt suffered in its execution across the far-flung empire. But it was implemented nonetheless, albeit with much hesitation on the part of local commanders. Half a year on, the Grand Vizier Rāmī Meḥmed Paşa found himself writing letters to a catechism teacher in Bosnia, in a not so gentle tone, requesting that he please implement Feyżullah's plan of an empire-wide Islamic education. ${ }^{62}$ Similarly, a year after the initial order, Feyżullah continued directing the project by issuing the same order for the towns and villages at the ends of the military roads in the Balkans, on the Crimean frontier (Özü), and around Plovdiv and instructed his missionary teams to move on from Bosnia and toward Belgrade and Euboea. ${ }^{63}$ Two months later the project came to an early end when the mobs deposed the sultan and defiled Feyżullah's lifeless body. ${ }^{64}$

Feyżullah Efendi's plan to guarantee the Islamic knowledge of all the empire's inhabitants was not without precedent or parallel. The project was the culmination of an idea that had been circulating for decades in the advice

\footnotetext{
60 Süleymaniye Library, Hacı Mahmud Efendi MS 1565. This endorsement was then copied in subsequent documents like Esad Efendi MS 1618.

61 A condensed translation of this order and the previous ones is in Rifa'at Abou-El-Haj, Formation of the Modern State: The Ottoman Empire, Sixteenth to Eighteenth Centuries (Albany: State University of New York Press, 1991), 113-19; however, the references he provides seem incorrect. The originals are in BOA A.DVNSMHM.d 112: 724-57 (pp. 208-10). For the Istanbul ones, see 112: 909-11 (p. 255).

62 An Anthology of Letters by Rāmī Meḥmed Paşa, Österreichische Nationalbibliothek, MS AF 159 , ff. $5 \mathrm{ab}$.

63 BOA A.DVNSMHM.d 114: 316 (p. 68), 811-14 (pp. 184-85), 861-62 (p. 199).

64 The original teachers in Bosnia may have stayed on, see the receipt in BOA IE.ML 11210653.
} 
and morality manuals of others. ${ }^{65}$ He even simultaneously initiated a parallel project of nașinat for the empire's Christians by appointing his client, Awetik', to the position of Armenian patriarch for the express purpose of instilling "nașinat" to combat the 'heretical beliefs' that Catholic missionaries were spreading among the Armenian and Syriac populations. ${ }^{66}$ His disciplinary project was the culmination of a century of discourse around morality that emphasized the need for all of the empire's subjects to be responsible moral actors who reflected on their individual actions. Ensuring the moral certitude of the empire, both among Muslims and non-Muslims, was seen to be the only way to restore its grandeur and legitimize the sultan as the personal champion of the sharia. And yet, it is important to remember that this overambitious project failed and may have been one reason for the extreme animus he faced at the hands of the people. Perhaps his true sin was in going so far as to sideline even the sultan and make the office of şeyhülislam the primary upholder of the empire's morality. Or perhaps it was his vision of nașinat that the empire's subjects were simply unwilling to accept.

\section{N Ā B İ' 'S NASİHAT}

If Feyżullah Efendi attempted to inculcate his nașinhat through a campaign of mass education, then the poet Nābī (1642-1712) whispered his nașịhat into his listeners' ears as they lay alone reading his books. It provides a radical political vision, but one tied to a private moral transformation. His popular verse book of nasīhat, which often went simply by the name of nasīhatnāme but was formally titled Hayriyye, was one of the most popular works of Ottoman Turkish literature ever written and its overwhelming approval ensured Nābī's immense stature in the following centuries. ${ }^{67}$ Rare is the manuscript library that does not carry multiple copies of the Hayriyye today, with copy dates

65 Terzioğlu, "Ilm-i Hal," 99.

66 Many thanks to Cesare Santus for sharing his forthcoming article, "The Şeyhülislam Feyzullah Efendi and the Armenian Patriarch Awetik: A Case of Entangled Confessionalization?," in Tijana Krstić and Derin Terzioğlu, eds., Entangled Confessionalizations? Dialogic Perspectives on Community and Confession-Building Initiatives in the Ottoman Empire, 15th-18th Centuries (Piscataway, N.J.: Gorgias Press, forthcoming in 2020). The text of the order is in Ensar Köse, "Bir Hayalin Peşinde Yüz Yıl," Tarih Dergisi 63, 1 (2016): 41-88; the original order is in BOA, D.PSK, $2 / 48$, but it seems that a line is missing from when the order was copied by the scribe, making it somewhat difficult to understand.

67 Meserret Diriöz, Eserlerine Göre Nâbî (İstanbul: Fey Vakfi, 1994), 136. I have used the semicritical edition prepared by Mahmut Kaplan, given that the most commonly available version of Iskender Pala is transcribed from the nineteenth-century printed version and thus it is about twenty couplets short. Nābī, Hayriyye-i Nâbî (Inceleme-Metin), Mahmut Kaplan, ed. (Ankara: Ataturk Kultur Merkezi, 2008); Nābī and Iskender Pala, Hayriyye. This work became canonical to the point that it elicited famous responses such as the Lutfiyye of Sünbülzāde Vehbī. 
for its 1660 couplets ranging from shortly after it was written to the end of the nineteenth century. ${ }^{68}$

Nābī wrote the Hayriyye around 1701, the year before Feyżullah embarked on his campaign of nașịhat qua mass education. At the time Nābi was fifty-seven and his son, to whom he dedicated the manual, was seven. ${ }^{69}$ Like Feyżullah. Nābī was a provincial boy who made good in the capital, coming from the Arabic and Turkish-speaking town of Ruha (today's Urfa) to become a successful poet and kātib (secretary) in Istanbul and Edirne, where he had attached himself to the households of various grandees. The death of his chief patron, Mușāhib Mustafa Pasha, in 1686 propelled him to find employment as a secretary in the imperial chancellery of Mehmed IV, but his success was short-lived since he lost the job following the deposition of the sultan in $1688 .^{70}$ Like Feyżullah, whom he personally knew, ${ }^{71}$ he was unable to gain a foothold in the new political milieu and was forced to leave Istanbul and work as a tax collector in Aleppo. ${ }^{72}$

While we might view this move as a simple loss of position, and it might well have been, Nābī cast it as an act of self-made exile that allowed him to push a radical critique of society and state. He describes his transition to Aleppo by saying, "No longer preoccupied with estate | I've fallen into the corner of solitude."73 This "corner of solitude (künc-i 'uzlet)," though, had a second meaning of a "treasure (genc) of solitude," a sentiment he repeats to his son later on: "Don't leave the house, for that is paradise | in the corner of the house is the treasure of solitude." 74 It was a common enough act in his time. 'Uzlet, or withdrawal, was frequently used by intellectuals to present a deep critique of a society. Nābī would have known of Niyāz-i Miṣrī, who for much of the 1680s purposefully stayed in self-imposed exile on Limni Island as he publicly circulated a private diary that decried the legitimacy of the dynasty and issued prophetic and messianic claims, and of 'Abd al-Ghanī al-Nābulusī, who retreated into his house in Damascus only a few years before Nābī in purposeful rejection of the corrupt society and government of his time. ${ }^{75}$ All of these men, including Nābī, emerged from their exile with

68 The mass popularity of the Hayriyye differentiates it from similar but earlier works like Mustafa Ali's cantankerous poem, scribbled on the edge of a manuscript. Andreas Tietze, "The Poet as Critique of Society, a 16-Century Ottoman Poem," Turcica 9 (1977): 120-26, 145-60.

69 He was born in 1642, so arithmetic suggests the actual date of composition was 1699, or 1697 if one counts in hijri years, though the Kaplan has provided the date of 1701.

70 This convoluted history of patronage is reconstructed in Diriöz, Eserlerine Göre Nâbî, 58-84.

71 See the letters and kaṣides that Nābī sent to Feyżullah, in Bibliotheque Nationale de France, Suppl. Turc MS 378, ff. 184ab, 257b-58a.

2 BOA, AE.SMMD.IV 23.2592; IE.ML. 31.2991. By 1695, he seems to have actually been promoted to the defterdār of Şām province: IE.EV. 31.3565.

73 Nābī, Hayriyye, 180.

74 Ibid., 225.

75 See the aforementioned morality manual of Ibn Ma'n, al-Tamyizz, 270-79. After being pardoned from his exile, Niyāz-i Miṣrī chose to stay on Lemnos Island for another fourteen years. 
empire-wide fame and following. 'Uzlet was the practice of espousing a biting written critique of the public world through private reflection and withdrawal into the self.

The critique that Nābī developed in his solitude was frighteningly clear: the reigning institutions of Ottoman society were totally illegitimate. Yet this is only part of his nașinhat. The other part, so often overlooked but inseparable, is its moral exhortations on how to lead an ethical life within a corrupt society. ${ }^{76}$ Nābī moves between these two spaces, intertwining chapters that "forbid" an evil trait or class of society and "enjoin" good qualities until he slowly builds a screed damning the whole of Ottoman society. ${ }^{77}$

Nābī addressed his damning critique not to the sultan, as had been common in Ottoman advice literature, but to his own son, Ebu'l-Hayr. The choice is significant given that he would eventually declare the government illegitimate, and a play on a common classical framing of the king addressing his son, the prince. ${ }^{78}$ Yet, his fatherly advice was also meant to inculcate virtue in its original Latin sense of virtus, the qualities of being a man, vir. While any piece of advice addressed to a son may be burdened with metaphors of masculinity, Nābī's work possesses a deep sense that manhood is fragile, constantly threatened by a myriad of immoral acts in which any misstep can transform a man into an animal or a woman. ${ }^{79}$ Ever the poet, he plays by expounding on the connection between morality and manhood in his very first chapter on the importance of prayer. He stresses that no one is exempt from the obligations of Islam, no matter what their status or qualities may be or what esoteric or philosophical knowledge they possess. Not only is it doubtful whether anyone who

\footnotetext{
Derin Terzioğlu, "Sufi and Dissident in the Ottoman Empire: Niyazi-i Misri, 1618-1694" (PhD diss., Harvard University, 1999), 144-89. 'Abd al-Ghanī al-Nābulusī, Takmīl al-Nu'ūt fì Luzūm al-Buyūt (Perfecting Your Character by Staying at Home), Süleymaniye Library, Çelebi Abdullah MS 385, ff. 357-76. This action was modeled on Ghazali's retreat from and critique of society sixhundred years earlier. al-Ghazālī, Deliverance from Error (Louisville: Fons Vitae, 1999), 80-81, 87; Kaplan saw uzlet as a sign of weakness and political indifference rather than engagement. Mehmed Kaplan, "Nâbi ve 'Orta Insan' Tipi," Türk Dili ve Edebiyatı Dergisi 11 (Aralık 1961): $25-44$.

76 The large Turkish literature on Nābī casts him as either a poet or a political commentator. The better includes: Mine Mengi, Divan Şiirinde Hikemî Tarzin Büyük Temsilcisi Nâbî (Ankara: Ataturk Dil Kurumu, 1987); and Diriöz, Eserlerine Göre Nâbî. In the English-language literature, he has been the topic of an initial study of eighteenth-century religious life, in Marlene Kurz, Ways to Heaven, Gates to Hell: Fażlizāade 'Alī's Struggle with the Diversity of Ottoman Islam, Bonner Islamstudien 25 (Berlin: EB-Verlag, 2011), 249-68. Kurz casts him, without explanation, as a representative of mainstream religiosity.

77 On this notion, see Zilfi, Politics of Piety, 137-42; and Michael Cook's Commanding Right and Forbidding Wrong in Islamic Thought (Cambridge: Cambridge University Press, 2000).

78 The classic trope comes from the Qābūsnāma, but medieval Arabic literature also includes the framing of a father advising a son. Kaykavus ibn Iskandar, A Mirror for Princes: The Qabus Nama, Reuben Levy, trans. (London: Cresset Press, 1951).

79 E.g., Nābī, Hayriyye, 233, 235, 269.
} 
abandons prayer can truly be a man but, he explains to his son, the three gestures of prayer are represented in the very shape of the letters that spell out the word "man (adam)": Standing (أ), sitting (د), and prostrating (२).",80

Nābī expands his nașịhat to all aspects of life, often as a means of criticizing the social life of the new ruling classes whose success is fueled by debt and greed. Not only are silk and gold clothes frowned upon, but sumptuous garments in general. In place of sable, the belly fur of a fox will suffice. Satins, silks, and brocades are putrid; colorful clothes are unnecessary and one should wear plain fabrics and dress like one's peers. ${ }^{81}$ Nābī quips, "He who adorns his body with silk | whoever sees him says, "What is this?!" 82 The debts incurred to pay for these luxuries turn the lion-hearted into women and sages into dolts. ${ }^{83}$ Almost anything can leave one penniless: luxurious clothes, alchemy, gambling, or the quest for position. Even when giving charity there is no need for ostentation; rather than repairing a mosque or erecting a building it is better to feed the hungry. ${ }^{84}$ More than anything, debt is the primary motor of Nābī's analysis of society and the foundation of his advice. ${ }^{85}$ For this reason, he constantly tells his son to be happy with what little he has since the most humiliating thing possible is to ask another for financial help or a position. ${ }^{86}$

Much of Nābī's critique can be understood as a reorientation of the traditional social spaces of Ottoman governance. In particular, the meclis-the Islamic adaptation of the Greek symposium and the social foundation of intellectual and political life - is kept at arm's length. ${ }^{87}$ For this reason, Nābi devotes a chapter each to the sins of hypocrisy, lying, gossip, and the like. ${ }^{88}$ The extreme denunciation of gossip ( nakl) in the meclis is telling because in the fifteenth and sixteenth centuries it would have been regarded in a more positive light as "anecdotes (letā'if)," the verbal glue, detailed in the biographical dictionaries, that made the relatively limited intellectual elite cohere. By the late seventeenth century, however, with a much larger intellectual public, these anecdotes came to be regarded as vicious and destructive, and the antithesis of nașinat. ${ }^{89}$ Similarly, drinking and drug use, requisite for any scholarly gathering (meclis) or banquet (bezm), are strictly forbidden. There

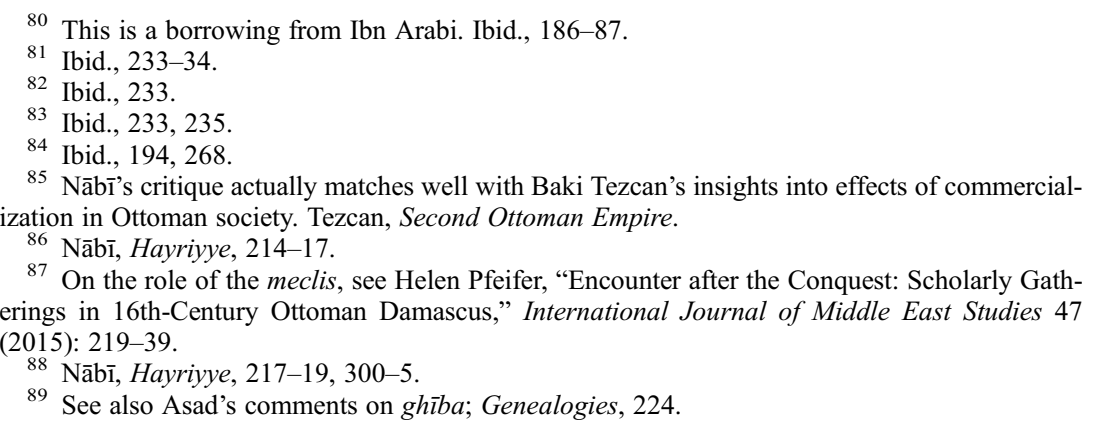


is nothing worse than being an addict, Nābī tells his son..$^{90}$ Games of chance, such as backgammon, are a trap created by Satan since they turn one into an irresponsible addict who stays up all night while his family goes hungry. ${ }^{91}$ Participating in the meclis might be inevitable, but wine, games, and other vices are all good excuses with which to escape this den of gossips and hypocrites.

For Nābī, like many seventeenth-century moralists, the family had become the new site of virtue and power. Nābī, of course, addressed his reading public through the figure of his biological son, but there are other signs as well. In contrast, again, to the male homosociability of the meclis, Nābi restricts the act of intercourse to women. Sex with young boys, not to mention men, is strictly forbidden since to have sex with a man is to waste one's sperm, an act that destroys life. A woman's womb is the proper location for this vital fluid. ${ }^{92}$ Yet, he cautions his son not to run out and marry solely for bodily pleasure. A marriage in haste can result in a wife of poor moral quality. Sexual needs should be sated with concubines, not boys, though even with them one had to be selective:

A Circassian concubine will be a disaster

Abaza girls are without chastity

Russian and Austrian and Frank and Hungarian

All of them incurable traitors

Not one of them will become a Muslim

Not one will enter the state of the true faith ${ }^{93}$

By arguing that certain ethnicities could never truly be Muslim, or lacked the proper morality, Nābi is suggesting not only that adherence to Islam is the only true measure of virtue, but also that even slaves are integral family members whose morality must be cultivated and monitored.

At first, Nābī's moral exhortations seem to strike a chord with those other more law-obsessed pietists of the seventeenth century, but what differentiates him is that in his view nașinat is an individual affair directed at oneself and not a societal prescription to be directed at others. Not only is he open to the intellectual and spiritual benefits of somewhat controversial pastimes like music, chess, and gazing upon beautiful boys, ${ }^{94}$ but he insists that one should not reproach others who do wrong. For example, he explicitly tells his son not to rebuke those whom he finds drinking. It is best to not become involved in their affairs in the first place. Rather than casting the first stone,

${ }^{90}$ Nābī, Hayriyye, 233.

${ }^{91}$ Ibid., 284.

92 Ibid., 212.

93 Ibid., 264

94 Ibid., 213-14, 254, 285. While he is generally against games, he finds chess a useful allegory for world affairs. Nābī's contributions to music even earned him a place in a biographical dictionary of the time. See Cem Behar, Şeyhülislâm'ın Müziği: 18. Yüzyllda Osmanlı/Türk Musılkisi ve Şeyhülislâm Es'ad Efendi'nin Atrabü'l-Âsâr'ı (Istanbul: Yapi Kredi Yayinları, 2010), 279. 
one should inspect one's own actions, because one is never free of $\sin .^{95} \mathrm{He}$ reinforces this advice by saying that one should never reproach someone in public or treat another with disrespect. ${ }^{96}$ In other words, Nābī's approach, while part and parcel of the pietistic turn, is a far cry from the nasīhat of Feyżullah and his forbearers, who attempted to enforce the classic edict of "commanding right and forbidding wrong" to create a moral society. ${ }^{97}$

Nābī's belief that one can only change oneself goes hand in hand with his championship of 'uzlet, a retreat from society to focus on one's private self. He tells his son,

Emerge not from the door of your house for months

Don't think of leaving your manor

Take your book in hand and block your door

Lest you receive any news from beyond your gate

Read histories and tales and stories of the prophets

It gives humans a good share of virtue

Were you to preoccupy yourself with hadī $\underline{s}$ and tefsìr

What happy days! What a wonderful plan!

Don't even think to speak with judges and pashas

You have no need to talk to that type

If someone wishes to enter your meclis

Try to silence them artfully ${ }^{98}$

Nābī's resolution is to seal oneself within one's house with one's books and reject the corrupt world outside. ${ }^{99} \mathrm{He}$ even prescribes a proper way for his son to receive his nașinhat, in a symposium of one, as he prepared for bed with a candle: "Every evening, may he light a beeswax candle | so that the smoke of sloth not enter his meclis." "Like his discourse on the family, politics and morality emerged from, and ideally stayed within, the bedroom.

Nābī's new morality was only needed because he considered Ottoman society and government completely corrupt. His critique, though, is not explicit in the beginning of the Hayriyye. Instead, it builds slowly as he details the various occupational paths that the son could follow, presenting a dark mirror of other works of nasinhat that survey the different classes of the realm and that culminate with the role of the king, a chapter that he omits. This same structure becomes a means to expound on the moral bankruptcy of

95 Nābī, Hayriyye, 231.

96 Ibid., 221-28.

97 This is not a rejection of the injunction to command right and forbid wrong, of course, but a redirection, in which he "forbids" entire segments and acts of Ottoman society, rather than correcting the behavior of neighbors.

${ }_{98}$ Nābī, Hayriyye, 244-45.

99 Ibid., $244-45$.

100 Beeswax candles produce no smoke when burned. Ibid., 314. 
almost all of Ottoman society - the grandees ('ayān), ${ }^{101}$ the holy men and saints, the military men ( $p \bar{a} s ̧ a)$, the jurists and the judges, and even the sultan. The crippling financial cost of participating in the political system drives anyone with ambitions of high position to take bribes and oppress the people to recoup those costs. The suffering of the common people (halk) bearing the burden of this constant oppression is a frequent refrain. For this reason, Nābī immediately tells his son to abandon dreams of attaining the position of a grandee and be content being a middling person. "Watch out, don't you ever desire to be a grandee | be the most middling person, that estate is enough for you." 102 The grandees - rapacious and greedy men who place no value in learning - are the antithesis of Nābī's new man, but even pashas and judges would sacrifice the people in their quest for position. ${ }^{103}$ Those who attempt to become pashas march straight into Hell, destroying the house of religion lest they risk not having their orders followed. ${ }^{104}$

As if the rapaciousness of the grandees and pashas were not enough, the poor also must suffer the charlatans claiming to be saints and holy men. In a chapter titled "On forbidding the pollution of lies and untruths," Nābī lets out a furious critique of charlatan shaykhs and saints living lavishly from the meager donations of the poor. The shaykhs of the Sufi orders are incredibly lazy and falsify dreams in order to proclaim their sanctity. ${ }^{105}$ All the accoutrements of Sufism - the cloak, the beads, and so forth - are simply a means to make money, a veil obstructing us from seeing the true saints. ${ }^{106}$ Now every pickpocket and laborer becomes a saint, Nābī claims. ${ }^{107}$ The time of true saints has passed, with everyone today simply a pale imitation. Rather than search for a perfect guide, a book will do. ${ }^{108}$ The seyyids, those who claim descent from the Prophet Muhammad, are just as bad. ${ }^{109}$ If there are true saints in the world, they are to be found among the poor, working toward divine union yet refusing riches. ${ }^{110}$

Nābī then shifts from a biting but general critique of the ills of society to a more systematic mode: no matter what his natural disposition or moral leanings, a pasha will be forced by the system to become a tyrant. He may at

101 In Nābī's rendering, 'ayān often means anyone who aims for high office rather than the more specific "provincial notables."

102 Nābī, Hayriyye, 237; see also 268.

103 Ibid., 239-40.

104 Ibid., 270.

105 Ibid., 247.

106 Ibid., 250.

107 Ibid., 251.

108 Nābī never totally rejected Sufis, though. He took a common position of stressing the need to combine esoteric and exoteric knowledge and appreciating the works of Ibn Arabi and Rumi. Ibid., $202-4$.

109 Ibid., 248.

110 Ibid., 253. 
first be a cultured scholar who knows well both religious and worldly affairs and is magnanimous and pure-hearted. He may even aid the poor and be aware of their problems and state that he does not desire riches. Yet everyone is eventually corrupted. Fear of death, or the need to have one's orders followed, or the debts acquired from running a political household compel one to become an oppressor. ${ }^{111}$ There is no way, in Nābī's eyes, to escape this inevitable corruption even if one wishes to be virtuous. ${ }^{112}$

Nābī then shifts from this systematic critique to declaring the illegitimacy of the government altogether. He first says that this massive injustice is only limited to the Ottomans and cannot be found in the lands of the Uzbeks, Indians (read Mughals), Christians, and Persians. ${ }^{113} \mathrm{He}$ continually brings up topoi of injustice - the lands lie fallow, the cities are turned into ruins, and brigands stalk every path - until he finally states, "The order of the world has surely been corrupted." 114 Nābī then posits a series of ideals of justice based on the following formula: if only the law, the sharia, were present then there would be no oppression, no insecurity, no sudden dismissal, no brigandry, and no rebellion by the subjects. All this would disappear if only the empire were run in accordance with the law. ${ }^{115}$ Since Nābī has spent the preceding thousand or so lines outlining that all these injustices do exist in plentitude and that the circle of justice has been shattered, he has for all intents and purposes declared the government illegitimate.

Lest Nābī's readers think that he is simply repeating the traditional critique of the political/military segments of the government in an attempt to promote the position of the religious scholars, he spends the next chapter declaring the judges and jurists to be completely corrupt as well. Starting with a critique of those jurists (muftis) who corrupt and adulterate the fetvas (legal opinions), he quickly moves on to his real target: the judges. Nābī declares the judicial system completely illegitimate due to the constant acceptance of bribes. Those who cannot pay receive no justice. The judges spend their bribes on tobacco (which was banned for periods) and rule on its permissibility happily. ${ }^{116} \mathrm{He}$ excoriates the judges and the muftis, saying it would be better to be a highway robber than to ravage the law (sharîa also literally means road) as a judge or jurist. ${ }^{117} \mathrm{He}$ ends the chapter damning them all for selling out the sharia. ${ }^{118}$ Even low-level bureaucrats (emin) and charitable foundation (vakif) managers become an object of Nābī's scorn. The former position is suitable only for the tame (ehli) who enjoy being ordered about.

\footnotetext{
111 Ibid., 271-73.

112 Ibid., 274-75.

113 Ibid., 276.

114 Ibid.

115 Ibid., 277.

116 Ibid., 281.

117 Ibid., 278.

118 Ibid., 282.
} 
As for the latter, the pay is low and it is difficult to make a foundation successful; one inevitably begins pilfering the foundation's proceeds and damns oneself to Hell. ${ }^{119}$ In the end, the judges and jurists are just like the pashas and the soldiery and the rest of the corrupt society. ${ }^{120}$

By this point, it seems that no segment of society is innocent save the poor and exploited farmer. ${ }^{121}$ The professor (muderris) seems to contribute the least evil to the world, but that is a difficult path to follow. Echoing the complaints of academics today, Nābi decries the lack of jobs and the need to move constantly to new positions with family in tow so as to move up the ladder. A man might succeed and climb the ranks, but along the way he will accumulate many enemies and much debt. And a few months after reaching the top he is summarily dismissed and sent to Rhodes where he will surely be taken prisoner by pirates. All this for a measly forty aspers. ${ }^{122}$ One could easily believe that Nābī's only solution is to abandon society altogether, to return to the aforementioned 'uzlet, as he exhorts his son to avoid the courts and divans, refuse to speak to judges and pashas, and not to go outside. ${ }^{123}$

In a completely corrupt society, Nābī argues, one can only act morally as an individual, not as a member of a social group. Yet there is one exception to his dismal view. The only truly virtuous men in Nābī's world are the senior secretaries of the Imperial Chancellery, the hacegān-i dīvān. Only they possess the moral qualities of Nābī's new man, "knowledgeable, learned, and meek, cultured, mild and patient," gaining their fame honorably and well paid to boot. $^{124}$ Perhaps not surprisingly, Nābī’s protégé, Rāmī Mehmed Paşa (d. 1704), had just become the grand vizier, the first of many chancellors to take up the post, and who may or may not have initiated the rebellion of $1703 .{ }^{125}$ In the absence of the sultan, and given Nābì's biting critique of all Ottoman institutions, Nābī may have been insinuating that these men were the ones with the true right to rule, that they best possessed the proper moral constitution for governing the empire.

\section{CONCLUSION}

This story comes to an end in the summer of 1703 with the deposition of a sultan and Feyżullah brutish death. Nābī, still in Aleppo, penned the following chronogram in Persian to commemorate the revolt:

119 Ibid., 289-91.

120 Ibid., 281.

121 Ibid., 264-68.

122 Ibid., 287-88.

123 Ibid., 244.

124 Ibid., 291.

125 On his rise, see Ekin Emine Tuşalp Atiyas, "Political Literacy and the Politics of Eloquence: Ottoman Scribal Community in the Seventeenth Century" (PhD diss., Harvard University, 2013). On his role in the rebellion, see Abou-El-Haj, 1703 Rebellion, 5. 
Following that villainous and corrupt mufti [Feyżullah]

When the people of Istanbul went mad and rebelled

I heard a line of a chronogram from the unseen

It said, "What is heard is not what was seen" (1703). ${ }^{126}$

What precisely is Nābī suggesting that we have failed to see? What is the ultimate moral of this tale? I have argued over the course of this article that Feyżullah and Nābī's intertwined story is more than an intriguing anecdote, but a means of writing anew the history of political thought in the early modern Middle East by focusing on their contending notions of nașinat, or "advice." Nașinat here is not the one commonly found in the secularized version of Ottoman political thought, but rather a field in which political power was expressed through the cultivation, exhortation, and enforcement of morality upon commoners and elites alike. While there were many competing visions of nasinhat on offer during the seventeenth century, they all developed from the values and experiments of the pietistic turn that emphasized that all the empire's subjects had the potential and responsibility to be moral - and thus political - actors, and to be so as individuals. In other words, these thinkers advanced a new political subjectivity, one based on the reorganization of politics around domesticity and private spaces. Here lies one major point of difference between Nābī's nașīhat and that of Feyżullah: while the clerics attempted to increasingly discipline and control private belief and even familial relations, Nābī cultivated and protected these private spaces as sites of political critique and resistance. As I stated in the introduction, we can only see this particular political regime of morality by adopting the insights of anthropologists of Islamic revival and secularism.

Anthropologists themselves might benefit, in turn, from a historical perspective derived from the Ottoman Empire. In their search for new understandings of Islamic revival, they logically have come to critique the very concept of secularism, which they connect to stronger European influence in the nineteenth century. European influence for the anthropologists is not the desacralizing influence of science, as earlier modernization theorists believed, ${ }^{127}$ but instead the transformative power of the colonial state which, the story goes, introduced a divide between the "secular" and the "religious," making the former a foundation for politics and consigning the latter to private life. Talal Asad, for example, identifies the emergence of secularism as a political project with the introduction of European legal codes in nineteenth-century Egypt and the relegation of the sharia to the sphere of family law, a space from which the state could bring the individual into being as a new political

\footnotetext{
${ }^{126}$ Nābī, Dīvān (Istanbul: Şeyh Yahya Efendi'nin Matbaası, 1292), 111.

127 Niyazi Berkes, The Development of Secularism in Turkey (Montreal: McGill University Press, 1964).
} 
actor and insert itself into modern ethics. ${ }^{128}$ While there were "formations of the secular" throughout human history, secularism as a political project did not exist prior to European colonialism because neither Arabic nor Turkish possessed words for "secularism" or the closely related concept of "society" until the late nineteenth century. ${ }^{129}$

Anthropologists' heavy focus on the past two centuries stems from their desire to critique the latent workings of contemporary secular liberalism. In the past few years, though, secularism and liberalism's hold on our society has grown more tenuous. Not only do critiques of secularism seem increasingly extraneous, but there has now emerged an unvoiced anxiety by some that questioning secularism (and therefore politically redeeming Islamist pietism) risks weakening democracy itself and inadvertently supporting autocratic regimes. ${ }^{130}$ Perhaps one way to break out of this entrapping dichotomy is to explore secularism's multiple histories in the Middle East, to imagine it beyond the confines of the liberal nation-state. Might there not have been other revolutions in morality that emerged prior to colonialism but which we have difficulty identifying given that they belonged to a culture with a different temporality and conceptual vocabulary? We might interpret Nābī's nașīhat, and specifically his call for spaces of private belief and individual morality, as a form of secularism that creates a "distinctive relation between state law and personal morality, such that religion became essentially a meter of (private) belief." "131 I draw this connection not to place the Ottoman Empire on some track to a fabled modernity, but rather to hint at ways that the politics fostered by the pietistic turn might have expressed itself, even until today.

It happens that in the months preceding and following Feyżullah's demise the city of Istanbul initiated an experiment of self-rule. The crowds gathered and took control of the city, and rejected the imperial government's nașīhat. ${ }^{132}$ They also, however, rejected Nābī's former protégé, the grand vizier Rāmī Mehmed Paşa, whom the Janissaries singled out for invective after Feyżullah. ${ }^{133}$ The city's inhabitants instead chose to follow their own path: "ignoring four hundred years of dynastic rule," the city's provisional leader, Çalık Ahmed, "tried to cultivate in the public (ortalığl) the false belief" that "the state should be run by mass gathering and assembly (cumhûr-l cemiyyeti ve tecemmu'-l devleti)."134 Did this aborted proto-

128 Asad, Formations, 205-56.

129 Ibid., 206-8.

130 A partial, but different, critique is in Ussama Makdisi, "The Limits of Anti-Secularist Critique," Politics, Religion \& Ideology 17, 1 (2016): 77-79.

131 Asad, Formations, 205.

132 See note 17.

133 Vatican Library, MS Borg.turc.39, ff. 97b.

134 Naima Mustafa Efendi, Târîh-i Naî̀mâ, 1877. 
democratic uprising emerge from new understandings of nașịhat circulating in the seventeenth century? Chroniclers like Naima, who wrote the above passage after the new sultan, Ahmed III, had established himself, dismiss the uprising as opportunistic anarchism and the event was eventually erased from the pages of history. Historians today have likewise suggested that it was a foiled attempt to establish a Janissary oligarchy. ${ }^{135}$ For the moment, we can only speculate about the cultural origins and significance of this political experiment. Nābī himself, though, urges us to take a second look at this forgotten revolution and understand that "what is heard is not what was seen."

\begin{abstract}
Over the sixteenth and seventeenth centuries an immense body of morality literature emerged in the Ottoman Empire as part of a widespread turn to piety. This article draws upon the anthropology of Islamic revival and secularism to reassess this literature's importance and propose a new view of the history of political thought in the empire. It does so through a close analysis of a fundamental concept of Ottoman political life: "nașinhat, " or "advice." Historians have used "advice books" to counter the presumption that the Ottoman Empire declined after the sixteenth century, but in doing so they have overlooked the concept's broader meaning as "morally corrective criticism." I analyze two competing visions of nasinhat at the turn of the eighteenth century to reveal how the concept was deployed to politically transform the empire by reforming its subjects' morality. One was a campaign by the chief jurist Feyżullah Efendi to educate every Muslim in the basic tenets of Islam. The other was a wildly popular "advice book" written by the poet Nābi to his son that both explicates a new moral code and declares the empire's government and institutions illegitimate. Both transformed politics by requiring that all subjects be responsible moral, and therefore political, actors. The pietistic turn, I argue, turned domestic spaces into political battlegrounds and ultimately created new, individualistic political subjectivities. This, though, requires challenging functionalist conceptions of the relationship between religion and politics and the secularist inclination among historians to relegate morality to the private sphere.
\end{abstract}

Key words: confessionalization, religious history, secularism, political thought, Ottoman Empire, nașīhat, Middle East, Islam, sharia

135 Tezcan, Second Ottoman Empire, 222-24; Cemal Kafadar, "Janissaries and other Riffraff of Ottoman Istanbul: Rebels without a Cause?" International Journal of Turkish Studies 13, 1 \& 2 (2007): 113-34, 133. 